\title{
Exploring Pro-Environmental Behaviour in FMCG Supply Chain
}

\author{
Jelena KONČAR, Radenko MARIĆ, Goran VUKMIROVIĆ*, Sonja VUČENOVIĆ
}

\begin{abstract}
This paper aims to define indicators that predict and shape the pro-environmental behaviour of manufacturers, transport companies, wholesalers and retailers as participants in the fast-moving consumer goods (FMCG) supply chain in the Western Balkans region. The main task is to determine the indicators which participants of FMCG supply chain consider as most important for the prediction of the pro-environmental behaviour concept. The findings showed a statistically significant correlation between the green indicators of pro-environmental behaviour, such as reverse logistics, the packaging waste management, energy consumption, ecological awareness, acting in accordance with green moral codes, compliances with legal and statutory ecological norms, interior hygiene and ecological infrastructure. The differences in these indicators are particularly visible among the observed participants in the supply chain and between the places of residence of employees (EU/non-EU countries). The test results served as the basis for defining a model for predicting pro-environmental behaviour. Future research should focus on extending the sample of research to the EU market, in order to make a better comparative analysis between EU and non-EU countries.
\end{abstract}

Keywords: ecological norms; employees; FMCG; pro-environmental behaviour; supply chain

\section{INTRODUCTION}

Manufacturers, transport companies, wholesale and the retail sector, act as production and service activities along the entire FMCG supply chain which implies an interactive relationship between buyers, sellers and environment, and thus it is necessary that all parties are satisfied with the final transaction [1-4]. The research results by Young et al. [4] show that the concept of proenvironmental behaviour applied by supply chains members directly reflects higher satisfaction of all participants in the production to sales transactions. The results of other studies [5, 6] go in this favour and clearly show that the concept of pro-environmental behaviour implemented by the management of FMCG supply chains implies the growth in sales and transactions, as well as greater customers' satisfaction with the transaction result. Customers are motivated to purchase products and services from companies that behave in a socially and proenvironmentally responsible manner [7].

Recent studies [8,9] confirm the found results and indicate that consumers opt for re-purchase and reconsumption of goods and services if the behaviour of supply chain participants is recognized as socially and proenvironmentally responsible. Other studies show a high degree of a direct correlation between consumer's satisfaction and pro-environmental behaviour conduct of companies as supply chain participants, ranging between 0.750 and $0.850[10,11]$.

In recent years, increasing importance has been put on promoting sustainable behaviour in the sense that all economic entities should promote pro-environmental behaviour across the FMCG supply chain through frequent interactions with market and consumers [4]. Sustainable business activities in the sector of production, transport, wholesale and retail should be directed towards transparency and reduction of environmental impact [12], which, according to the results of studies, directly reflects the behaviour of consumers and other participants in the supply chain [13].

The authors [14] are increasingly committed to ensuring sustainability through green supply chain management (GSCM) practices. Following this practice,
FMCG supply chain participants aim to examine the factors of enterprise sustainability and to manage them strategically. Studies [15] show that such a strategic orientation, based on the application of the GSCM concept, is the best approach to improve sustainability performance. The results showed that reverse logistics, green shopping, eco-design, environmental awareness, and environmental infrastructure improve all components of sustainable performance.

Based on the presented aspects, the aim of this study lies in the precise definition of indicators that predict and shape the pro-environmental behaviour of producers, transport companies, wholesalers and retailers in the Western Balkans market. In the Western Balkans region, the issue of pro-environmental behaviour is at the very beginning of implementation due to the still nonharmonized legislation with EU Directives, underdeveloped environmental awareness among market players and weak institutional protection and controls [16, 17]. In addition, Western Balkans was selected because of the adequate representativeness of the sample of research reflected in different levels of FMCG supply chains development across countries, the ability to apply comparative analysis between EU and non-EU countries, as well as the fact that it is a market with about 20 million consumers.

The obtained results and performed tests make the FMCG supply chain management aware of the real importance of the analysed indicators. They can thus shape pro-environmental workplace and model responsible proenvironmental employees who will responsibly undertake all business decisions and activities relating to customers and market. As confirmed by the research conducted by Grubor et al. [19] and Poór et al. [20], companies with a built concept of CSR and pro-environmental behaviour are more efficient and show better results in the implementation of HRM practices. These are the companies that form workers with pro-environmental responsible habits [20]. Such established system within an organization results in higher loyalty of consumers to the subject supply chain, meaning they will again choose to buy products and services of that supply chain, and thus directly affect its profitability, market share and 
competitiveness [21]. The practical importance of this paper is reflected in the fact that based on the analysed results certain measures and incentives can be proposed which the management of companies, competent institutions and trade policymakers have to undertake in order to ensure greater application of pro-environment behaviour in the sectors of production, transport, wholesale and retail.

The paper is structured as follows. After the Introduction, the Literature Review summarizes the most important theoretical aspects of how important proenvironmental behaviour is, especially with regard to FMCG service industries. The literature review provides the basis for establishing the research hypotheses. The Methodology shows the research sample and the basic testing stages using One-way analysis of variance, Multiple regression analysis and Pearson correlation. Research results and hypotheses testing are presented in the Results chapter. Discussions on obtained results are covered in the Discussion chapter. The test results are used for modelling a pro-environmental behaviour. Finally, the Conclusion summarizes the most important results of the study and provides suggestions for future research.

\section{LITERATURE REVIEW}

Pro-environmental behaviour can be interpreted in several ways. Some authors think pro-environmental behaviour encompasses economic, social, legal and philanthropic responsibilities which differ depending on psychological variables of an individual (such as subjective resource assessments) [22, 23], while others see it as management based on creating a sustainable balance between economic, social, and environmental objectives [24]. Pro-environmental behaviour can also be regarded as a dedication to sustainability concept to the work that contributes to the economic development of a company and at the same time, improves the life quality of employees, the local community, the public, and the society as a whole [25]. Complex interpretation of pro-environmental behaviour prompted the authors to distinguish between four structural parts of this concept: Part 1 - knowledge of basic principles of sustainability, Part 2 - all business activities of company's management must be aligned with the interests of the society and environment, Part 3 business policy and business strategy must be founded on ethical values, and Part 4 - environment protection, the sustainability of resources, concern for future generations and other social issues should be significantly represented in corporate management, planning and setting of business goals [20-25].

Similarly, pro-environmental behaviour in business is viewed as employee's sense of identification with the company, job and consumers, on one hand, that is, with the environment and demands of society, on the other hand $[25,26]$. This sense is expressed in employees' motivation to make efforts in their work, to take responsibility and be willing to learn how to do their job in the best possible way, taking into account the profitability of the company, as well as meeting sustainability principles [24-26]. Proenvironmental business behaviour can actually be regarded as the management's philosophy and its way of thinking, where employees' responsibility cannot be exclusively related to the company (corporate resources) but must be extended to consumers, environment, the public, society and the state [27]. Through their actions, employees should not be guided solely by corporate interests and profitability but should take into account the principle of sustainable development, that is, to contribute equally to corporate "good" on the one hand, and to the needs of the environment and public "good" on the other [21, 22, 24, 25].

Pro-environmental behaviour is very important in the FMCG supply chains, where numerous business operations such as the disposal of unused products, packaging, transportation of packaging waste, hygiene in handling food, fruits and vegetables depend directly on employees who are in contact with end consumers at the same time. If applied, the concept of pro-environmental behaviour directly affects the quality of product, quality of service and final sales act, but also consumers' satisfaction and their loyalty towards the chosen supply chain [28]. Corporate pro-environmental behaviour could be observed as a set of indicators that employees should get familiar with and apply in order to act in a pro-environmental responsible manner. In this context, many studies emphasize the importance of the following green indicators of pro-environmental behaviour in the sectors of production, transport, wholesale and retail of fast-moving consumer goods, such as:

1) Reverse logistics [29-31] pro-environmental behaviour implies that the production process must not degrade the environment, both during and after the production process, in the usage phases, and especially in the product disposal stages (reverse logistics). Accordingly, managing the environmental performance of the disposal of unused products becomes one of the priorities in the preservation of the environment. Employees in FMCG supply chains need to know the procedures for disposing of unused products, expired products, defect products, scrap, etc.

2) Packaging waste [32] handling packaging waste is considered by some authors $[29,30]$ to be an integral part of reverse logistics, however, in the broader context, in addition to the return packaging disposal procedure, this indicator also applies to the handling of non-returnable packaging or waste. It is essential for retailers to be involved in the non-returnable waste disposal chain in order to fully utilize it in the recycling process, as well as to have a direct impact on reducing packaging waste in the environment.

3) Energy consumption [33] the participants of FMCG supply chains are facing heavy consumption of electricity and water, fuel for transport and delivery of goods, energy for production, energy for maintaining ventilation systems in warehouses, retail outlets, etc. A growing number of reports emphasizes that retail facilities represent enormous consumers of energy because they have a large number of direct power supply devices such as refrigerators, freezers, cold shelves, cold storages, air conditioning units, etc. Devices often work continuously to ensure usability and maintain the quality and freshness of products (e.g. meat and meat products, fish, milk, dairy products, etc.). Proenvironmental behaviour in this segment involves the application of the principles of rationalization of energy use and increase of energy efficiency through the use of energy-efficient devices (COP > 3.6; EER > 3.2), as well 
as maximum responsible behaviour of employees in the sector of production, transport, wholesale and retail.

4) Ecological awareness [22, 23] represents the subjective perception of employees about the importance of sustainable consumption, protection of the environment, the number of resources spent, concern for future generations, etc. The authors emphasize that it often depends on income, education level, subjective sense of well-being, gender and social values of the individual [22]. 5) Acting in accordance with green moral codes implies employees' compliance with environmental codes of conduct [34]. Green moral codes or environmental codes of conduct are generally binding rules of conduct that each institution, organization and company independently enact. They contain ways of complying with the general principles of sustainability that are tailored to the scope of the code maker's business activities.

6) Compliances with legal and statutory ecological norms [35] refers to the adoption of all legal acts, norms, standards and regulations governing and controlling proenvironmental behaviour. These are, above all, EU Directives, such as Packaging and Packaging Waste Directive 94/62 / EC, Waste Management Directive 75/442 / EEC, Hazardous Waste Management Directive 91/689 / EEC, Impact on Environment Strategic Assessment Directive 2001/42 / EC, and many others, which must be fully harmonized with national and regional legislative standards.

7) Hygiene is one of the most important indicators, it is especially important for retail stores specializing in the sale of meat and meat products, fish and seafood, milk and dairy products, fruits and vegetables, etc. The most dangerous problem is the contamination of food with potential environmental pollutants. In addition to the willingness and training of employees to maintain hygiene along the entire FMCG supply chain, institutional support is also needed in the form of the introduction of HACCP (Hazard Analysis Critical Control Points), IFS (International Food Standard), BRC (British Retail Consortium) and other standards [36].

8) Ecological infrastructure [37] is the connection of effectively constructed green corridors and lanes (e.g. sorting and removal of waste, use of solar panels, developed recycling systems, etc.) with blue (water-based), green (vegetated), and grey (non-living) landscapes. In this context, the participants of FMCG supply chain, especially retail outlets and retail chains with large warehouses, should build the concept of eco-infrastructure through stronger collaboration with other supply chain participants, recycling companies, waste transport and disposal companies, green and water surface maintenance companies, etc.

Based on the theoretical aspects presented, the aim of this paper is to construct a regression model for predicting pro-environmental behaviour in the FMCG supply chains through the analysis and testing of the real impact of green indicators. For the purposes of the research, FMCG supply chains of the Western Balkans region were selected due to the different degree of their development observed by countries (e.g. Croatia and Serbia vs. North Macedonia), as well as different approaches to sustainability issues (e.g. EU/non-EU countries), thus ensuring representativeness of the sample. Also, the largest logistic companies, distributors and retail chains in the Western Balkans (Delta Transport logistics, Lidl, Spar, Delhaize, Metro, etc.) operate in the region, employing about $15 \%$ of the working population. Differences to core business (production, transport, wholesale and retail) and respondents' demographic characteristics, such as gender, income, education level, and subjective sense of well-being, form specific research strata.

\section{METHODOLOGY \\ 3.1 Aim and Hypotheses}

Based on the analysed theoretical views on proenvironmental behaviour in the FMCG supply chains, a basic research objective has been defined to determine the existence of a statistically significant correlation between pro-environmental behaviour and green indicators [29-38] such as reverse logistics, packaging waste management, energy consumption, ecological awareness, acting in compliance with green moral codes, compliances with legal and statutory environmental standards, interior hygiene and ecological infrastructure. As different intensity of significance and correlation with proenvironmental behaviour can be expected for these indicators, the set research goal was operationalized through the first group of research hypotheses: $\mathrm{H}_{1(\mathrm{a})}$ reverse logistics gives statistically significant prediction on pro-environmental behaviour in the FMCG supply chain of the Western Balkans region, $\mathrm{H}_{1(\mathrm{~b})}$ - packaging waste management gives statistically significant prediction on pro-environmental behaviour in the FMCG supply chain of the Western Balkans region, $\mathrm{H}_{1(\mathrm{c})}$ - energy consumption offers statistically significant prediction on proenvironmental behaviour in the FMCG supply chain of the Western Balkans region, $\mathrm{H}_{1(\mathrm{~d})}$ - ecological awareness gives statistically significant prediction on pro-environmental behaviour in the FMCG supply chain of the Western Balkans region, $\mathrm{H}_{1(\mathrm{e})}$ - green moral codes offer statistically significant prediction on pro-environmental behaviour in the FMCG supply chain of the Western Balkans region, $\mathrm{H}_{1(\mathrm{a})}$ - legal and statutory ecological norms also provide statistically significant prediction on pro-environmental behaviour in the FMCG supply chain of the Western Balkans region, $\mathrm{H}_{1(\mathrm{~g})}$ - hygiene provides statistically significant prediction on pro-environmental behaviour in the FMCG supply chain of the Western Balkans region, $\mathrm{H}_{1(\mathrm{~h})}$ - ecological infrastructure gives statistically significant prediction on pro-environmental behaviour in the FMCG supply chain of the Western Balkans region.

Some studies [22] state that an individual's perception of environmental problems depends on gender, income, education level, subjective sense of well-being and country of origin. In this context, the abovementioned group of demographic factors has been tested through the following hypotheses: $\mathrm{H}_{2(\mathrm{a})}$ - the prediction of green indicators on pro-environmental behaviour is different in terms of gender of employees, $\mathrm{H}_{2(\mathrm{~b})}$ - the prediction of green indicators on pro-environmental behaviour is different in relation to employee income levels, $\mathrm{H}_{2(\mathrm{c})}$ - the prediction of green indicators on pro-environmental behaviour is different in terms of family status of employees, $\mathrm{H}_{2(\mathrm{~d})}$ - the prediction of green indicators on pro-environmental behaviour is different from the subjective sense of well- 
being of employees and $\mathrm{H}_{2(\mathrm{e})}$ - the prediction of green indicators on pro-environmental behaviour is different depending on the country of origin of employees (EU/nonEU countries).

Academic research [31, 38-40] indicates that there are differences among supply chain participants, especially regarding the acceptance of logistics concepts, modern technology, consumer relations, social responsibility, environmental relations, etc. In this regard, in line with the set research goal, as a separate research hypothesis, the existence of differences between the predictions of proenvironmental behaviour of employees based on green indicators in the manufacturing, transport, wholesale and retail sectors of fast-moving consumer goods will be tested. The third research hypothesis is: $\mathrm{H}_{3}$ - the prediction of green indicators on pro-environmental behaviour differs depending on the core business participants of the FMCG supply chain in the Western Balkans region.

\subsection{Research Variables}

Testing the hypotheses involved the inclusion of a large number of variables in the research. Based on related studies, the core of business such as manufacturing, transportation, wholesale and retail [31, 38-40] and employee demographics such as gender, income, education level, subjective sense of well-being, and country of origin [22], were selected as the predictor grouping variables. The dependent variable is the pro-environmental behaviour in the supply chains of the Western Balkans region, which was evaluated on the basis of the influence of independent variables of the interval type of measurement. Eight green indicators were selected as predictors of the interval type of measurement whose impact was individually defined and analyzed in the results of various studies [22, 23, 2937]. The contribution of this research is in its comprehensiveness, integrated analysis and precise definition of the importance of each indicator within the FMCG supply chain. Green indicators include reverse logistics [29-31], packaging waste management [32], energy consumption [33], ecological awareness [22, 23], acting in accordance with green moral codes [34], compliances with legal and statutory ecological norms [35], hygiene [36] and ecological infrastructure [37].

Respondents were asked to rank the importance of these indicators on pro-environmental behavior, i.e., to assess the impact of given variables on environmental behavior in the companies in which they work. Each indicator was operationalized through three statements. Reverse logistics defines knowledge of procedures for disposal of unused products, knowledge of procedures for handling defected products, and disposal of scrap. Packaging waste management was measured as the degree to which employees are familiar with the procedures for disposing of non-returnable packaging, the recycling process, and ways to reduce packaging waste. Energy consumption was measured through the use of energyefficient devices, energy consumption (electricity, water, fuel), and the degree of self-responsible behavior of employees in the function of energy-saving. Ecological awareness is defined as the subjective perception of employees about the importance of sustainable consumption, the amount of resources spent, and care for future generations. Acting under green moral codes contains the respondents' attitudes about the necessity of having ecological codes of conduct, the possibilities of acting upon them, and the sanctions for possible violations of essential environmental provisions. Compliances with legal and statutory ecological norms were measured through the respondents' attitudes about acting according to legal acts, standards, and regulations which regulate and control pro-ecological behavior. Hygiene was measured through the indoor cleanliness, the degree of danger of food contamination, and the degree of application of standards (HACCP, IFS, BRC). Ecological infrastructure is the degree of construction of blue (water-based), green (vegetated), and gray (non-living) landscapes.

\subsection{Research Sample}

The research was conducted on a sample of 521 employees in production, transport, wholesale and retail of fast-moving consumer goods, in the Western Balkans (Delta Transport Logistics, Imlek, Lidl, Spar, Delhaize, Metro, Idea, Mercator, Univerexport, etc.). The given sample falls into the category of large statistical samples. The research included employees who are familiar with business activities, logistics processes and physical manipulation operations at selected companies. The research was conducted in the Western Balkan countries (Croatia - CRO, Serbia - SRB, Bosnia and Herzegovina B\&H, Montenegro - MNG and Northern Macedonia MKD) except Albania, where it was not possible to provide an adequate sample of respondents. Respondents were equally divided by country (CRO: $n=116$; SRB: $n=119$; B\&H: $n=100$; MNG: $n=96$; MKD: $n=90)$, core of business (production $(p)=114$; transport $(t)=134$; wholesale $(w)=118$; retail $(r)=155)$ and demographic categories (Tab. 1).

\begin{tabular}{|c|c|c|c|c|c|}
\hline Gender & $n$ & Structure & Income & $n$ & Structure \\
\hline Male & 294 & $56.4 \%$ & up to $400 €$ & 187 & $35.9 \%$ \\
\hline \multirow[t]{2}{*}{ Female } & 227 & $43.6 \%$ & $400-800 €$ & 225 & $43.2 \%$ \\
\hline & & & over $800 €$ & 109 & $20.9 \%$ \\
\hline $\begin{array}{c}\text { Education } \\
\text { level }\end{array}$ & $n$ & Structure & $\begin{array}{c}\text { Sense of } \\
\text { well-being }\end{array}$ & $n$ & Structure \\
\hline Qualified & 104 & $20.0 \%$ & $\begin{array}{l}\text { Bellow } \\
\text { average }\end{array}$ & 129 & $24.8 \%$ \\
\hline $\begin{array}{l}\text { Highly } \\
\text { qualified }\end{array}$ & 240 & $46.1 \%$ & Average & 258 & $49.5 \%$ \\
\hline $\begin{array}{c}\text { University } \\
\text { degree }\end{array}$ & 177 & $33.9 \%$ & $\begin{array}{c}\text { Above } \\
\text { average }\end{array}$ & 134 & $25.7 \%$ \\
\hline
\end{tabular}

\subsection{Research Procedure and Data Analysis}

The research was conducted electronically on the basis of an anonymous questionnaire distributed to HR services of the largest participants of FMCG supply chain in the Western Balkans in the period from September to November 2019. The questionnaire response rate was $74 \%$. The questionnaire was designed based on previous studies [22, 41, 42]. Following general information on demographics, employees were asked to rank the significance of each of the green indicators on proenvironmental behaviour through the three statements made. A standard Likert-type scale of measurement (0 - no 
significance; 5 - very high significance) was used for ranking. Pro-environmental behaviour, as a dependent variable, was also estimated through three claims by the Likert scale. The data scale is relevant for evaluating the attitudes and opinions of employees, as confirmed by the Cronbach Alpha coefficient, whose value for each of the tested indicators is closer to 1 than 0 , indicating a good level of reliability and validity of the applied scale (Tab. 2).

Table 2 Values of Cronbach Alpha coefficient

\begin{tabular}{|c|c|}
\hline Green indicators & Cronbach's alpha \\
\hline Reverse logistics & 0.954 \\
\hline Packaging waste & 0.818 \\
\hline Energy consumption & 0.729 \\
\hline Ecological awareness & 0.814 \\
\hline Moral codes & 0.772 \\
\hline Legal and statutory ecological norms & 0.805 \\
\hline Hygiene & 0.892 \\
\hline Ecological infrastructure & 0.911 \\
\hline For all items & 0.883 \\
\hline
\end{tabular}

The standard statistical package for social sciences SPSS 20 was used to collect and process the obtained data. Descriptive statistics were used to describe the basic statistical indicators of the research sample. Statistical methods of One-way analysis of variance, Multiple regression analysis and Pearson correlation were used to check and test the hypotheses.

\section{RESULTS}

The obtained average answers (ranks) of the respondents to the offered statements about the importance of green indicators for predicting pro-environmental behaviour in the FMCG supply chain of the Western Balkans are presented in the following table (Tab. 3), together with the most significant descriptive indicators. As the focus of the research is on manufacturers, transport companies, wholesalers and retailers as the main participants in the FMCG supply chain, the answers will be particularly selected in the sectors indicated.

The research results show that the highest average grade $(M=4.22)$ is recorded by the legal and statutory ecological norms indicator, which employees in FMCG supply chains see as the most important predictor of proenvironmental behaviour in the Western Balkans market. In terms of sectors, retailers give most importance to legal and statutory ecological norms, which is especially important since they are the last link in the FMCG placement of products that make direct contact with final consumers $(M=4.58)$. The highest agreement on the importance of this indicator is recorded by employees of manufacturing companies $(S D=0.55)$. Manufacturers also recorded a relatively high average score $(M=4.47)$, which supports the conclusion that the most responsible companies in terms of compliance with environmental legislation and standards are at the beginning and the end of the FMCG supply chain. At the same time, at the level of the entire sample, respondents show the second-highest degree of agreement regarding the average grade for this indicator $(S D=0.65)$. This result is expected for the Western Balkans region, where many previous studies [1618] have confirmed that employees have high confidence in legal and statutory norms and believe that they ensure socially responsible corporate behaviour. Next in importance is the packaging waste management indicator $(M=4.13 ; S D=0.72)$. Retailers $(M=4.32, S D=0.53)$ stated the highest significance and highest agreement on this item. This is also an expected answer given the fact that employees in the retail sector have the problem of disposing of large quantities of used logistic packaging systems (e.g. cardboard boxes, pallets, crates for storing fruits and vegetables, etc.). Particularly important in FMCG supply chain is the recycling segment of packaging waste, which according to the objectives of EU Directive $94 / 62$ / EC should be $55 \%$ or $60 \%$ for glass packaging, $50 \%$ for metal packaging, $60 \%$ for cardboard and paper, $22.5 \%$ for plastic packaging and $15 \%$ for wooden packaging [43].

Table 3 Descriptive statistics of green indicators

\begin{tabular}{|c|c|c|c|c|}
\hline Green indicators & Min & $\operatorname{Max}$ & Mean & $S D$ \\
\hline Reverse logistics & 1.00 & 5.00 & 3.45 & 0.69 \\
\hline Production & 2.00 & 5.00 & 4.00 & 0.61 \\
\hline Transport & 2,00 & 5.00 & 3.50 & 1.12 \\
\hline Wholesale & 2.00 & 5.00 & 3.10 & 0.72 \\
\hline Retail & 1.00 & 5.00 & 3.20 & 1.28 \\
\hline Packaging waste & 2.00 & 5.00 & 4.13 & 0.71 \\
\hline Production & 2.00 & 4.00 & 3.95 & 1.53 \\
\hline Transport & 2.00 & 5.00 & 4.14 & 0.88 \\
\hline Wholesale & 2.00 & 5.00 & 4.00 & 0.72 \\
\hline Retail & 2.00 & 5.00 & 4.32 & 0.53 \\
\hline Energy consumption & 2.00 & 5.00 & 3.82 & 0.62 \\
\hline Production & 2.00 & 5.00 & 3.80 & 0.94 \\
\hline Transport & 2.00 & 5.00 & 3.65 & 0.74 \\
\hline Wholesale & 3.00 & 5.00 & 3.80 & 0.57 \\
\hline Retail & 3.00 & 5.00 & 4.15 & 0.48 \\
\hline Ecological awareness & 1.00 & 4.00 & 3.17 & 1.14 \\
\hline Production & 2.00 & 4.00 & 3.14 & 1.45 \\
\hline Transport & 1.00 & 3.00 & 2.65 & 0.91 \\
\hline Wholesale & 1.00 & 4.00 & 3.45 & 1.28 \\
\hline Retail & 1,00 & 4.00 & 3.51 & 0.92 \\
\hline Moral codes & 1.00 & 4.00 & 2.88 & 1.07 \\
\hline Production & 1.00 & 4.00 & 3.59 & 1.63 \\
\hline Transport & 1.00 & 3.00 & 2.09 & 0.57 \\
\hline Wholesale & 1.00 & 3.00 & 2.23 & 0.85 \\
\hline Retail & 2.00 & 4.00 & 3.56 & 1.04 \\
\hline $\begin{array}{l}\text { Legal and statutory } \\
\text { ecological norms }\end{array}$ & 1.00 & 5.00 & 4.22 & 0.65 \\
\hline Production & 2.00 & 5.00 & 4.47 & 0.55 \\
\hline Transport & 1.00 & 4.00 & 3.79 & 0.61 \\
\hline Wholesale & 1.00 & 4.00 & 3.86 & 0.78 \\
\hline Retail & 2.00 & 5.00 & 4.58 & 0.60 \\
\hline Hygiene & 1.00 & 4.00 & 3.21 & 1.27 \\
\hline Production & 2.00 & 4.00 & 2.78 & 0.68 \\
\hline Transport & 1.00 & 4.00 & 3.14 & 1.62 \\
\hline Wholesale & 1.00 & 4.00 & 3.45 & 1.49 \\
\hline Retail & 2.00 & 4.00 & 3.47 & 0.77 \\
\hline Ecological infrastructure & 1.00 & 5.00 & 3.79 & 1.16 \\
\hline Production & 2.00 & 5.00 & 3.86 & 0.73 \\
\hline Transport & 2.00 & 5.00 & 3.98 & 0.41 \\
\hline Wholesale & 1.00 & 5.00 & 4.22 & 1.08 \\
\hline Retail & 1.00 & 4.00 & 2.89 & 1.37 \\
\hline
\end{tabular}

A significant average ranking is recorded by energy consumption and energy efficiency $(M=3.82)$, which is characterized by the highest degree of agreement between the respondents regarding the average importance of this indicator on pro-environmental behaviour $(S D=0.62)$. This indicator is most relevant to the sustainability issue of the entire FMCG supply chain and needs to be given special attention since it is the economic entities that are one of the largest energy consumers (e.g. manufacturers, large storage systems, retail chains). Unless all participants 
in the FMCG supply chain commit themselves to rationalization in the consumption of electricity, water, fuel, use of energy-efficient devices, etc., an imbalance in the environment will be created and problems in the further sustainable development of the Western Balkans market will arise. Supply chain participants are aware of the importance of sustainability as shown by the high average ratings for retailers $(M=4.15)$, wholesalers and manufacturers $(M=3.80)$. Above-average grades were assigned to environmental infrastructure $(M=3.79)$ and reverse logistics $(M=3.45)$ by the employees. Manufacturers are most in favour of introducing a reverse logistics system $(M=4.00 ; S D=0.61)$, while wholesale infrastructure $(M=4.22 ; S D=1.08)$ emphasizes the importance of environmental infrastructure. The least significance was assigned to the hygiene indicator $(M=$ 3.21) and still underdeveloped environmental awareness among employees $(M=3.17)$. The very last position is the adherence and acceptance of voluntary environmental codes of conduct $(M=2.88)$.

In order to determine which indicators correspond together, that is, in order to test their individual mutual correlation the following Correlation matrix was applied. (Tab. 4).

Table 4 Correlation matrix of green indicators

\begin{tabular}{|c|c|c|c|c|c|c|c|c|}
\hline & 1 & 2 & 3 & 4 & 5 & 6 & 7 & 8 \\
\hline Reverse logistics & 1 & & & & & & & \\
\hline Packaging waste & 0.754 & 1 & & & & & & \\
\hline Energy consumption & $0.895 *$ & $0.736 *$ & 1 & & & & & \\
\hline Ecological awareness & 0.404 & $0.753 * *$ & $0.774 * *$ & 1 & & & & \\
\hline Moral codes & -0.492 & 0.363 & $0.496^{*}$ & $0.599 * *$ & 1 & & & \\
\hline $\begin{array}{c}\text { Legal and statutory ecological } \\
\text { norms }\end{array}$ & $0.761^{*}$ & $0.837 * *$ & $0.359 *$ & $0.478^{*}$ & $0.538 * *$ & 1 & & \\
\hline Hygiene & 0.428 & $-0.879 *$ & 0,338 & 0,561 & -0.256 & $0.518^{*}$ & 1 & \\
\hline Ecological infrastructure & $0.349 * *$ & 0.513 & 0.514 & $0.663 *$ & 0.547 & $0.582 * *$ & 0.491 & 1 \\
\hline
\end{tabular}

${ }^{* *}$ Correlation is significant at the level $1 \%$; ${ }^{*}$ Correlation is significant at the level $5 \%$

The largest correlation can be read off between legal and statutory ecological norms and packaging waste $(r=$ 0.837, $p<0.01)$, environmental awareness and energy consumption $(r=0.774, p<0.01)$ and environmental awareness and packaging waste management $(r=0.753, p$ $<0.01)$. The results show that employees, who rank the importance of legal and statutory ecological norms highly, also attach great importance to the handling and disposal of packaging waste, that is, those who value ecological awareness highly do the same with energy consumption and packaging waste. Significant correlations are also evident between reverse logistics and ecological infrastructure, green moral codes and ecological awareness, and between legal and statutory ecological norms and green moral codes. To test the first group of hypotheses $\mathrm{H}_{1(\mathrm{a})}-\mathrm{H}_{1(\mathrm{~h})}$ on predicting pro-environmental behaviour based on green indicators in the FMCG supply chain of the Western Balkans market, a multiple regression analysis was applied.

Table 5 Testing the individual indicators contribution

\begin{tabular}{|c|c|c|c|c|}
\hline & \multicolumn{2}{|c|}{ Stand. coefficient } & \multirow[b]{2}{*}{$t$} & \multirow{2}{*}{ Sig. } \\
\hline & Beta & St. Error & & \\
\hline (const.) & 0.78 & 1.172 & 3.477 & 0.000 \\
\hline Reverse logistics & $0.573 *$ & 0.473 & 0.417 & 0.054 \\
\hline Packaging waste & $0.754 * *$ & 0.365 & 0.942 & 0.000 \\
\hline Energy consumption & $0.667^{*}$ & 0.392 & 0.519 & 0.001 \\
\hline $\begin{array}{l}\text { Ecological } \\
\text { awareness }\end{array}$ & 0.093 & 0.501 & 1.042 & 0.641 \\
\hline Moral codes & -0.581 & 0.670 & 0.186 & 0.966 \\
\hline $\begin{array}{l}\text { Legal and statutory } \\
\text { ecological norms }\end{array}$ & $0.827 * *$ & 0.487 & 1.140 & 0.000 \\
\hline Hygiene & $0.448 *$ & 0.291 & 0.306 & 0.034 \\
\hline $\begin{array}{l}\text { Ecological } \\
\text { infrastructure }\end{array}$ & $0.382 *$ & 0.583 & 0.734 & 0.024 \\
\hline
\end{tabular}

${ }^{* \star}$ Correlation is significant at the level $1 \% ;{ }^{*}$ Correlation is significant at the level $5 \%$

Based on the Enter method, which tests the correlation of all predictor variables (green indicators) with dependent variable (pro-environmental behaviour), the results showed that the regression model was statistically significant $(F(500 ; 7)=2.64, p<0.01)$, that is, confirms the existence of a significant correlation between the analyzed variables. The given model describes $78.1 \%$ of the criterion variable. The individual contribution of green indicators is presented in the following table (Tab. 5).

The above table shows that pro-environmental behaviour can be predicted on the basis of legal and statutory ecological norms $(B=0.827, p<0.01)$ and packaging waste management $(B=0.754, p<0.01)$. These indicators show the greatest relative importance in predicting the dependent variable. The results confirm some previous findings of studies $[32,35]$ which see the basis of pro-environmental behaviour in accepting and acting on legislative standards and efficient operations of packaging waste disposal, through recycling, production of returnable packaging, proper sorting of packaging materials, etc. A significant correlation is also evident in the indicators of energy consumption and energy efficiency of the entire FMCG supply chain, which is at the limit of statistical significance of $1 \%(B=0.667, p=0.01<0.05)$. This necessitates a greater rationalization of energy use by employees in the sectors of production, transport, wholesale and retail while increasing the energy efficiency of the production, storaging and retail facilities themselves (e.g. better insulation, more efficient cooling systems, ventilation systems, etc.) and achieving greater efficiency with the used devices (cooling cabinets and shelves, cold storages, etc.). Indicators of reverse logistics $(B=0.573, p$ $<0, .05)$, hygiene $(B=0.448, p<0.01)$ and ecological infrastructure $(B=0.382, p<0.05)$ are highly correlated. In contrast to previous studies [20-22, 32], the results of this study show that ecological awareness about the necessity of pro-environmental behaviour among FMCG supply chain employees in the Western Balkans region is not developed enough $(B=0.093, p>0.05)$ and a very low importance is given to voluntary environmental codes and adherence to them $(B=-0.581, p>0.05)$. The testing 
conducted shows that the research hypotheses $\mathrm{H}_{1(\mathrm{a})}, \mathrm{H}_{1(\mathrm{~b})}$, $\mathrm{H}_{1(\mathrm{c})}, \mathrm{H}_{1(\mathrm{f})}, \mathrm{H}_{1(\mathrm{~g})}$ and $\mathrm{H}_{1(\mathrm{~h})}$ are accepted. This means that any changes in the indicators of reverse logistics, packaging waste management, energy consumption, compliances with legal and statutory environmental standards, interior hygiene and ecological infrastructure have a statistically significant effect on pro-environmental behaviour. The correlation is positive, which means that with the increasing importance of these indicators, employees are more determined to behave in a pro-environmental manner in the FMCG supply chain of the Western Balkans, and vice versa. At the same time, this approach and employee behaviour along the entire FMCG supply chain ensures a higher degree of sustainability of the entire chain for all current and potential participants. This means that manufacturers need to keep an eye on ways of exploiting raw materials and resources, optimizing energy, and finding renewable sources of supply. Transport companies need to rationalize their consumption of motor fuels, reduce their emissions of harmful gases through the use of energy vehicles [44], participate in reverse logistics and timely disposal of packaging, etc. Some authors [45] also propose the mandatory application of mathematical models to reduce the fixed costs of vehicle use and the cost of fuel consumption in the supply chain. Finally, wholesalers and retailers need to implement energy-efficient appliances, streamline electricity and water consumption, use energyefficient systems to maintain optimum storage and retail space temperatures, etc. The other two hypotheses $\mathrm{H}_{1(\mathrm{~d})}$ and $\mathrm{H}_{1(\mathrm{e})}$ are rejected, that is, ecological awareness and moral environmental codes do not predict statistically significant pro-environmental behaviour. These are the two indicators that competent institutions, trade policymakers and supply chain management should focus on, develop and promote. Without an awareness of the importance of proenvironmental behaviour, it is impossible to take sustainability issues seriously, achieve a rational level of resource consumption and protect the environment.

The second objective of the research refers to the impact of demographic characteristics on proenvironmental behaviour, that is, depending on the demographic characteristics of employees in the FMCG supply chain, the prediction of green indicators on proenvironmental behaviour is different. Multiple regression analysis was applied to test the second group of research hypotheses $\mathrm{H}_{2 \text { (a) }}-\mathrm{H}_{2(\mathrm{e})}$. To obtain more accurate data in testing hypothesis $\mathrm{H}_{2(\mathrm{e})}$ about the relationship between proenvironmental behavior and the respondents' country of origin, the stated sample $(n=521)$ was corrected. In the fundamental sample, respondents are mostly employed by global companies that operate in the Western Balkans region with unique environmental procedures and standards and a single sustainability policy. Namely, foreign companies' employees (such as Lidl, Metro, Imlek, Idea, Mercator and so on) have the same attitude towards pro-environmental behavior, as a result of unique procedures at the level of these companies, regardless of markets and the country in which the business is conducted. To obtain relevant data, a special stratum ( $n=$ 297) was formed to test hypothesis $\mathrm{H}_{2(\mathrm{e})}$ with only employees of local companies (Univerexport, Delta Logistics, Voli, Roda, etc.). The individual contribution of the analyzed indicators by gender, income, education level, well-being and country of origin is illustrated by the following table (Tab. 6).

Table 6Testing the individual indicators contribution

\begin{tabular}{|c|c|c|c|}
\hline $\begin{array}{l}\text { Demographic } \\
\text { factors }\end{array}$ & Green indicators & $F$ & Sign, \\
\hline \multirow[t]{8}{*}{ Gender } & Reverse logistics & 0.758 & 0.084 \\
\hline & Packaging waste & 1.114 & 0.581 \\
\hline & Energy consumption & 1.348 & 0.669 \\
\hline & Ecological awareness & 0.861 & 0.172 \\
\hline & Moral codes & 0.590 & 0.084 \\
\hline & $\begin{array}{l}\text { Legal and statutory } \\
\text { ecological norms }\end{array}$ & 0.882 & 0.418 \\
\hline & Hygiene & 0.451 & 0.822 \\
\hline & Ecological infrastructure & 0.642 & 0.565 \\
\hline \multirow[t]{8}{*}{ Income } & Reverse logistics & 0.256 & 0.432 \\
\hline & Packaging waste & $1.518^{*}$ & 0.041 \\
\hline & Energy consumption & $0.742 * *$ & 0.006 \\
\hline & Ecological awareness & $0.658 * *$ & 0.008 \\
\hline & Moral codes & 1.774 & 0.451 \\
\hline & $\begin{array}{l}\text { Legal and statutory } \\
\text { ecological norms }\end{array}$ & $1.048 * *$ & 0.007 \\
\hline & Hygiene & 0.478 & 0.493 \\
\hline & Ecological infrastructure & 0.718 & 0.566 \\
\hline \multirow[t]{8}{*}{ Education } & Reverse logistics & 0.820 & 0.157 \\
\hline & Packaging waste & $1.228 * *$ & 0.004 \\
\hline & Energy consumption & $1.117 *$ & 0.036 \\
\hline & Ecological awareness & $0.754 * *$ & 0.018 \\
\hline & Moral codes & 1.419 & 0.848 \\
\hline & $\begin{array}{l}\text { Legal and statutory } \\
\text { ecological norms }\end{array}$ & $0.562 *$ & 0.033 \\
\hline & Hygiene & 0.885 & 0.091 \\
\hline & Ecological infrastructure & 0.513 & 0.167 \\
\hline \multirow[t]{8}{*}{ Well-being } & Reverse logistics & 0.426 & 0.719 \\
\hline & Packaging waste & $1.270 *$ & 0.087 \\
\hline & Energy consumption & $1.261 * *$ & 0.000 \\
\hline & Ecological awareness & 1.338 & 0.651 \\
\hline & Moral codes & 0.472 & 0.866 \\
\hline & $\begin{array}{l}\text { Legal and statutory } \\
\text { ecological norms }\end{array}$ & $2.534 * *$ & 0.000 \\
\hline & Hygiene & $2.814 * *$ & 0.002 \\
\hline & Ecological infrastructure & 1.002 & 0.128 \\
\hline \multirow{8}{*}{$\begin{array}{l}\text { Country of } \\
\text { origin (EU/non- } \\
\text { EU) }\end{array}$} & Reverse logistics & 0.627 & 0.172 \\
\hline & Packaging waste & 0.911 & 0.576 \\
\hline & Energy consumption & $0.689 *$ & 0.017 \\
\hline & Ecological awareness & $1.337 * *$ & 0.003 \\
\hline & Moral codes & 0.661 & 0.395 \\
\hline & $\begin{array}{l}\text { Legal and statutory } \\
\text { ecological norms }\end{array}$ & $0.870 * *$ & 0.000 \\
\hline & Hygiene & 0.746 & 0.501 \\
\hline & Ecological infrastructure & $0.881 * *$ & 0.001 \\
\hline
\end{tabular}
$5 \%$

Based on the results of multiple regression analysis, hypotheses $\mathrm{H}_{2(\mathrm{~b})}, \mathrm{H}_{2(\mathrm{c})}, \mathrm{H}_{2(\mathrm{~d})}$, and $\mathrm{H}_{2(\mathrm{e})}$ are accepted, which means that the prediction of green indicators on proenvironmental behaviour differs depending on income, level of education, satisfaction with the well-being and the country of origin of employees in the FMCG supply chain. The results show that the differences in income are mostly reflected in energy consumption $(p<0.01)$, environmental awareness $(p<0.01)$ and legal and statutory ecological norms $(p<0.01)$. Viewed by strata, it is noticeable that respondents with higher incomes (over $800 €$ ) give higher ranks to energy consumption and show a high level of environmental awareness, unlike respondents with belowaverage incomes. In the education level group, the biggest differences appear in packaging waste $(p<0.01)$ and environmental awareness indicators $(p<0.01)$. Respondents with a university degree are more aware of environmental issues and give greater importance to 
packaging waste disposal processes. Moderate differences are present in the obligation to rationalize energy consumption $(p<0.05)$ and the implementation of legislative norms $(p<0.05)$. In the well-being satisfaction stratum, above-average satisfied employees value energy consumption $(p<0.01)$, legislative environmental standards $(p<0.01)$ and hygiene more $(p<0.01)$. Regarding the respondents' country of origin, the largest differences are observed in terms of legal and statutory ecological norms $(p<0.01)$ primarily, as a result of the inconsistency of legislative policy between EU and nonEU countries. Significant differences are also read in the respondents' awareness of the need for pro-environmental behavior $(p<0.01)$, as well as in the degree of construction of ecological infrastructure $(p<0.01)$. The surprising result is that the impact of green indicators on pro-environmental behaviour does not depend on the gender. In other words, respondents of a different gender have identical views on the intensity of the correlation between green indicators and pro-environmental behaviour in the retail sector of the Western Balkans. Thus, the research hypothesis $\mathrm{H}_{2(a)}$ is not accepted.

As the focus of this research is on the main participants of the FMCG supply chain in the Western Balkans, it is necessary to determine whether differences in predicting green indicators on pro-environmental behaviour depend on differences between supply chain participants. In this context, the multiple regression analysis methods will be used for testing the third hypothesis $\mathrm{H}_{3}$ set by the researchers. The results of the regression analysis by the observed strata are presented in the following table (Tab. 7)

Table 7 Testing the individual indicators contribution by participants of FMCG supply chain

\begin{tabular}{|c|c|c|c|c|c|c|c|c|}
\hline & \multicolumn{2}{|c|}{ Production $(p)$} & \multicolumn{2}{|c|}{ Transportation $(t)$} & \multicolumn{2}{|c|}{ Wholesale $(w)$} & \multicolumn{2}{|c|}{ Retail $(r)$} \\
\hline & Beta & Sig. & Beta & Sig. & Beta & Sig. & Beta & Sig. \\
\hline (const.) & 0.66 & 0.007 & 0.94 & 0.002 & 0.52 & 0.000 & 0.82 & 0.000 \\
\hline Reverse logistics & $0.462 * *$ & 0.000 & $0.623 *$ & 0.033 & 0.771 & 0.363 & $0.684 *$ & 0.042 \\
\hline Packaging waste & $0.594 *$ & 0.045 & $0.818 * *$ & 0.000 & $0.626^{* *}$ & 0.001 & $0.712 * *$ & 0.000 \\
\hline Energy consumption & $0.581 * *$ & 0.002 & $0.738 * *$ & 0.004 & $0.814 * *$ & 0.000 & $0.658 *$ & 0.001 \\
\hline Ecological awareness & 0.112 & 0.651 & 0.025 & 0.681 & 0.119 & 0.273 & 0.084 & 0.423 \\
\hline Moral codes & 0.471 & 0.584 & -0.692 & 0.530 & -0.763 & 0.584 & -0.692 & 0.748 \\
\hline Legal and statutory ecological norms & $0.836^{* *}$ & 0.007 & $0.737 *$ & 0.047 & $0.749 * *$ & 0.002 & $0.802 * *$ & 0.000 \\
\hline Hygiene & 0.611 & 0.426 & 0.349 & 0.794 & $0.594 *$ & 0.027 & $0.533 *$ & 0.003 \\
\hline Ecological infrastructure & $0.782 * *$ & 0.043 & $0.692 * *$ & 0.000 & $0.416^{* *}$ & 0.000 & $0.292 *$ & 0.024 \\
\hline
\end{tabular}

${ }^{* *}$ Correlation is significant at the level $1 \% ;{ }^{*}$ Correlation is significant at the level $5 \%$

The table below shows that the obtained regression equations are statistically significant for each of the observed FMCG supply chain sectors $(p:(F(100 ; 7)=2.95$, $p<0.01 ; t:(F(120 ; 7)=2.79, p<0.01 ; w: F(100 ; 7)=2.95$, $p<0.01 ; r:(F(120 ; 7)=2.79, p<0.01)$ The result suggests that the differences between employees in the manufacturing, transport, wholesale and retail are significantly affected by differences in the importance of green indicators in predicting pro-environmental behavior. Therefore, the $\mathrm{H}_{3}$ hypothesis is accepted. Proenvironmental behaviour and sustainability in the manufacturing sector can be predicted based on legal and statutory ecological norms $(B=0.836)$, environmental infrastructure $(B=0.782)$, energy consumption $(B=0.581)$ and reverse logistics $(B=0.462)$. Transport companies, besides environmental infrastructure $(B=0.737)$ and energy consumption $(B=0.738)$, give great importance to the disposal of packaging and packaging waste $(B=0.818)$. In addition to the above indicators, for wholesalers and retailers the hygiene indicator appears as very significant ( $w: B=0.594, p<0.05 ; r: B=0.533, p<0.05$ ), which is an expected result given the need to maintain high hygienic conditions in storage and sales areas, and especially in contact with final consumers and while working with perishable food products. Indicators that do not have a statistically significant impact on FMCG supply chain participants are environmental awareness and moral codes, which confirms that there is a lack of sufficient information regarding the importance and necessity of proenvironmental behaviour and sustainable development in the Western Balkans region.

\section{DISCUSSION}

Conducted research, analyses and testing of hypotheses have shown that green indicators statistically predict significant pro-environmental behaviour in the FMCG supply chain of the Western Balkans. Multiple regression analysis has proven that employee proenvironmental behaviour can be predicted based on reverse logistics, packaging waste management, energy consumption, compliances with legal and statutory environmental standards, interior hygiene and ecological infrastructure. While the impact of the indicators of ecological awareness and green moral codes are not considered sufficiently significant. In accordance with this statement, the following regression model for predicting pro-environmental behaviour on the level of the entire FMCG supply chain is defined:

$$
\begin{aligned}
& Y_{1}=0.78+0.573 x_{1}+0.754 x_{2}+0.667 x_{3}+0.827 x_{6}+ \\
& +0.448 x_{7}+0.382 x_{8}
\end{aligned}
$$

In the presented model, $Y_{1}$ represents proenvironmental behaviour in the FMCG supply chain that depends on green indicators $x$, namely: $x_{1}$ - reverse logistics, $x_{2}$ - packaging waste management, $x_{3}$ - energy consumption, $x_{6}$ - legal and statutory environmental standards, $x_{7}$ - interior hygiene and $x_{8}$ - ecological infrastructure. The remaining two indicators $x_{4}$ - ecological awareness and $x_{5}$ - moral codes are not included in the model because they have no significance on the dependent variable.

The model clarifies which factors are important for predicting the pro-environmental behavior of the supply 
chain participants and it can be used as a part of some subsequent analyzes and tests. In other words, this model can serve as a starting point for further research, to know how and in what way to predict and promote proenvironmental behavior through optimization of indicators whose relative importance is more significant. The obtained results confirm the results of previous research [27-34], which consider the treatment of green indicators generally binding for achieving a satisfactory level of proenvironmental behaviour, sustainability and sustainability of resources. The results of studies [22] also partially confirm that individual psychological variable and demographic factors differently determine proenvironmental behaviour. This implies that employees' approach to the concept of retail sustainability differs in terms of different educational level, income, subjective sense of well-being and job satisfaction and country of origin. Their pro-environmental behaviour is not influenced by gender.

The results obtained indicated in particular the differences in approach to sustainability and green indicators between supply chain participants. This is in line with the results of some previous studies [31] which confirmed that supply chain participants face different problems with regard to particular business activities, that is, each sector has specific priorities that it seeks to fulfil. In this context, it is possible to define the following four regression models for predicting pro-environmental behaviour by sectors of production (2), transportation (3), wholesale (4) and retail (5):

$$
\begin{aligned}
& Y_{2}=0.66+0.462 x_{1}+0.594 x_{2}+0.581 x_{3}+0.836 x_{6}+ \\
& +0.782 x_{8} \\
& Y_{3}=0.94+0.623 x_{1}+0.818 x_{2}+0.738 x_{3}+0.737 x_{6}+ \\
& +0.692 x_{8} \\
& Y_{4}=0.52+0.626 x_{2}+0.814 x_{3}+0.749 x_{6}+0.594 x_{7}+ \\
& +0.416 x_{8} \\
& Y_{5}=0.82+0.684 x_{1}+0.712 x_{2}+0.658 x_{3}+0.802 x_{6}+ \\
& +0.533 x_{7}+0.292 x_{8}
\end{aligned}
$$

In order to gain a clearer insight into the differences between the green indicators according to the analyzed regression models, comparisons will also be presented graphically (Fig. 1).

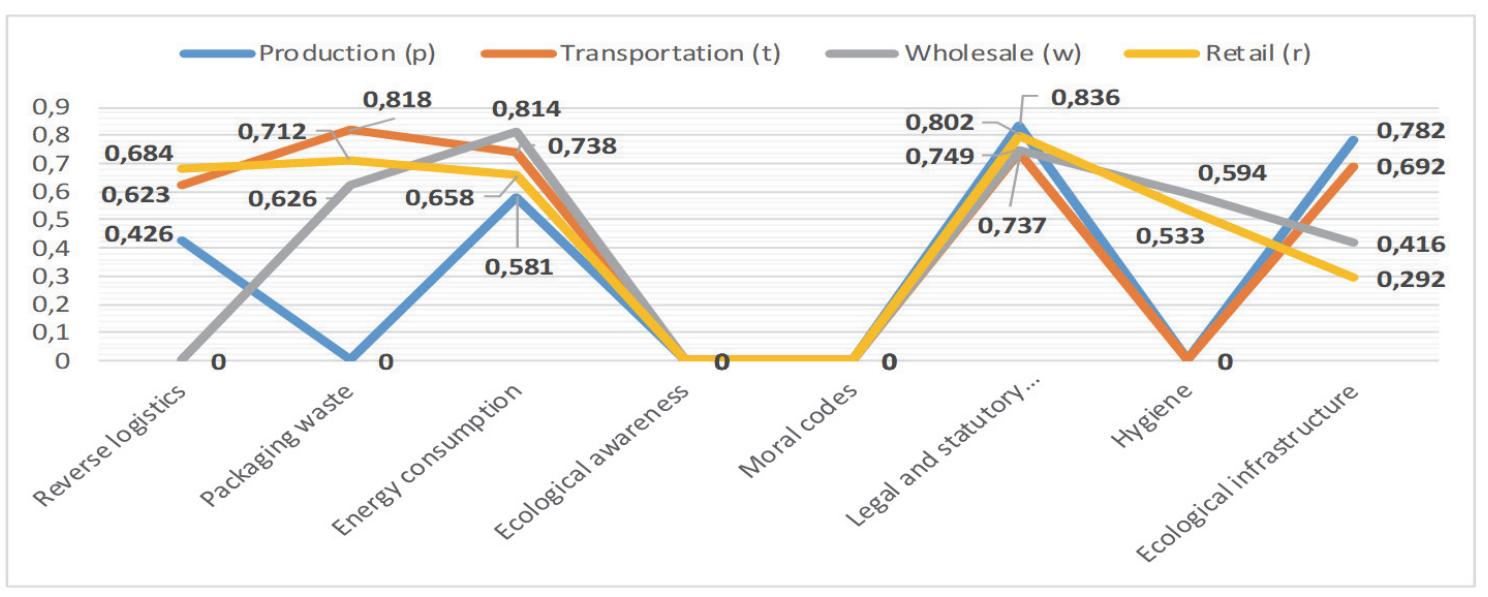

Figure 1 Comparative analysis of the importance of green indicators by FMCG supply chain sectors in the Western Balkans region

In the graph above, indicators that do not show a statistically significant correlation with pro-environmental behaviour are assigned a value of 0 . Comparative analysis of the defined regression models reveals discrepancies in the analyzed green indicators such as ecological infrastructure, packaging waste and hygiene. Also, the answers of the respondents were harmonized with regard to ecological norms, energy consumption and packaging waste. On the other hand, there is a lack of environmental awareness and moral codes among all FMCG supply chain participants. In order to stimulate the rise of environmental awareness among employees in the Western Balkan countries, trade policymakers, relevant institutions (chambers of commerce, relevant ministries, secretariats, and professional associations) must undertake a whole set of measures, among which are the following: 1) Complete harmonization of national regulations with the EU Directives: Packaging and Packaging Waste Directive Directive 94/62 / EC and Directive 720/2015, Waste Management Directive 75/442 / EEC, Hazardous Waste Management Directive 91/689 / EEC, Impact on
Environment Strategic Assessment Directive 2001/42 / $\mathrm{EC}$, etc. This measure is particularly significant because the indicator legal and statutory ecological norms is rated by employees as the most important predictor of proenvironmental behaviour; 2) Introduce and adopt all necessary international and national eco-standards such as ISO 14000: 2015 - Environmental management, ISO 14001: 2015 - Environmental management system, ISO 50001: 2011- Energy management system, HACCP / ISO22000: 2005 - Food Safety Management System FSMS, ISO13429: 2005 - standard for defining criteria for reuse of packaging and many others; 3 ) Adopting national sustainable development and environmental strategies in line with the objectives and provisions of the UN Agenda 2030; 4) Financial subsidies, measures and credits to encourage sustainability through the development of recycling systems, increase the energy efficiency of facilities, audit of wastewater systems, waste disposal, etc.; 5) Transition from traditional grey to green-blue ecological infrastructure; 6) Organizing educational programs and courses on the necessity and importance of pro- 
environmental behaviour, sustainable development and preservation of the environment for employees and consumers in the placement of FMCG. Studies [46] state that innovation efforts of management and organizational structures towards the development of pro-environmental

behaviour significantly reduce the environmental problem; 7) Obligation of reporting and informing transparently about the status of the environment, etc.

\section{CONCLUSION}

The need for a study of pro-environmental behaviour in employee behaviour in the FMCG supply chain of the Western Balkans results from the fact that this segment of service is the fastest-growing sector of the economy [48, 49] with enormous environmental impact in the Western Balkans market. In this regard, the main objective of research was to create a model of pro-environmental behaviour and to precisely define the importance of indicators such as reverse logistics, packaging waste management, energy consumption, environmental awareness, acting in accordance with green moral codes, compliances with legal and statutory environmental standards, interior hygiene and environmental infrastructure.

In this context, an empirical survey was conducted among 521 employees in the sector of production, transport, wholesale and retail in the Western Balkans market and three hypotheses groups were tested. The first group of hypotheses, concerning the statistically significant prediction of pro-environmental behaviour based on green indicators, was confirmed for reverse logistics, packaging waste management, energy consumption, compliances with legal and statutory ecological norms, interior hygiene and ecological infrastructure. The second group of hypotheses about the importance of demographic factors to the concept of proenvironmental behaviour was confirmed for the categories of income, education level, subjective sense of well-being and the respondents' place of residence. Within the third hypothesis, the correlation between differences between FMCG supply chain participants and differences in the importance of green indicators for predicting proenvironmental behaviour was tested. The hypothesis is confirmed, which suggests that the differences between the entities in the supply chain determine the differences in the importance of the green indicators. Based on the tests conducted, a model of pro-environmental behaviour of employees in the FMCG supply chain was defined. Defined model of pro-environmental behaviour is significant in practice. It can assist management of FMCG supply chain in defining and creating pro-environmental responsible workplace and forming pro-environmental employees, which affects directly the profitability of supply chain through better meeting the needs of consumers and environment than their competitors do.

The shortcomings of the research. The lack of this research is reflected in the geographical limitation of the research to the FMCG supply chain of the Western Balkans region. The objective reasons for choosing a given sample lie in the availability of data, the ability to effectively interview respondents and the authors' familiarity with regional supply chain activities. A disadvantage may also be the statements which have been pre-formulated in the questionnaires.

Suggestions for future research. Future research should focus on extending the sample of research to the EU market, in order to make a better comparative analysis between EU and non-EU countries. The research should also include the consumer segment and test the significance of the subgroups within the indicators analyzed, for example, the use of paper bags, the use of quick-breakable packaging, the importance of eco-labelling, etc. In addition, future research should consider the reasons for the discrepancy in the impact of certain demographics on green indicators, such as differences in understanding environmental awareness based on education levels, etc. Such a systematic approach would complement the scientific view of the importance of pro-environmental behaviour in the FMCG supply chain of Western Balkans.

\section{REFERENCES}

[1] Li, Y., Yang, Z. J., Chen, C., Song, Y. X., Zhang, J. J., \& Du, D.W. (2018). An integral algorithm for instantaneous uncut chip thickness measuring in the milling process. Advances in Production Engineering \& Management, 13(3), 297-306. https://doi.org/10.14743/apem2018.3.291

[2] Petković, G. \& Užar, D. (2020). Marketing channels in value creation and delivery of cheese in the Republic of Serbia. Anali Ekonomskog Fakulteta u Subotici, 56(43), 101-115. https://doi.org/10.5937/AnEkSub2001101P

[3] Zic, J., Zic, S. (2020). Multi-criteria decision making in supply chain management based on inventory levels, environmental impact and costs. Advances in Production Engineering \& Management, 15(2), 151-163. https://doi.org/10.14743/apem2020.2.355

[4] Young, C. W., Russell, S. V., Robinson, C. A., \& Chintakayala, P. K. (2018). Sustainable retailing-influencing consumer behaviour on food waste. Business Strategy and the Environment, 27(1), 1-15. https://doi.org/10.1002/bse.1966

[5] Jones, P. \& Comfort, D. (2020). Sustainability bonds and green bonds within the retail sector. International Journal of Sales, Retailing \& Marketing 2020, 9(1), 37-43.

[6] Jurčević, Ž., Bogićević, I., Đokić, D., \& Matkovski, B. (2019). Information Technology as a Factor of Sustainable Development of Serbian Agriculture. Strategic Management, 24(1), 41-46. https://doi.org/10.5937/StraMan1901041J

[7] Öztay, H. \& Birinci, E. (2020). The corporate social responsibility perception and sustainable consumption behaviour of the employees in forest products industry enterprises: the case of the Western Black Sea section. Forestist, 70(1), 36-43. https://doi.org/10.5152/forestist.2020.19025

[8] Leary, R. B., Vann, R. J., Mittelstaedt, J. D., Murphy, P. E., \& Sherry Jr, J. F. (2014). Changing the marketplace one behaviour at a time: Perceived marketplace influence and sustainable consumption. Journal of Business Research, 67(9), 1953-1958. https://doi.org/10.1016/j.jbusres.2013.11.004

[9] Buenstorf, G. \& Cordes, C. (2008). Can sustainable consumption be learned? A model of cultural evolution. Ecological Economics, 67(4), 646-657. https://doi.org/10.1016/j.ecolecon.2008.01.028

[10] Welsch, H. \& Kühling, J. (2010). Pro-environmental behaviour and rational consumer choice: Evidence from surveys of life satisfaction. Journal of Economic Psychology, 31(3), 405-420. https://doi.org/10.1016/j.joep.2010.01.009

[11] Ramkissoon, H. \& Mavondo, F. T. (2015). The satisfactionplace attachment relationship: Potential mediators and 
moderators. Journal of Business Research, 68(12), 25932602. https://doi.org/10.1016/j.jbusres.2015.05.002

[12] Wei, C. F., Chiang, C. T., Kou, T. C., \& Lee, B. C. (2017). Toward sustainable livelihoods: Investigating the drivers of purchase behaviour for green products. Business Strategy and the Environment, 26(5), 626-639. https://doi.org/10.1002/bse.1942

[13] Munir Dad, A. (2012). Interactive communication channels and their appropriateness for the FMCG business. International Journal of Management and Business Research, 2(3), 253-269.

[14] Habib, M., Bao, Y., Nabi, N., Dulal, M., Asha, A. A., \& Islam, M. (2021). Impact of Strategic Orientations on the Implementation of Green Supply Chain Management Practices and Sustainable Firm Performance. Sustainability, 13(1), 340. https://doi.org/10.3390/su13010340

[15] Abdullah, R., Mohamad, M. N., \& Thurasamy, R. (2021). Enhancing Sustainable Performance Through Green Supply Chain Management Practices: a Study of Malaysian Manufacturing Firms. Religación, 5, 163-170. https://doi.org/10.46652/rgn.v5i23.610

[16] Petrović, N. \& Škrbić, B. (2016). Ecological value orientations and readiness for activism in Serbia. Collection of Papers - Faculty of Geography at the University of Belgrade, 64, 47-71. https://doi.org/10.5937/zrgfub1664047P

[17] Barjaktarović, V. (2016). Uticaj porodične socijalizacije na razvoj ekološke svjesti kod dece I omladine-primjer Crne Gore. Sociološki diskurs, 6(11), 35-54. https://doi.org/10.7251/SDSR1611037B

[18] Poór, J., Slavić, A., Katalin, T., Berber, N., Kerekes, K., \& Karoliny, Z. (2020). Benchmarking in human resource management in focus of Central and Eastern Europe in the light of CRANET research. Strategic Management, 25(1), 21-28. https://doi.org/10.5937/StraMan2001021P

[19] Grubor, A., Berber, N., Aleksić, M., \& Bjekić, R. (2020). The influence of corporate social responsibility on organizational performances: A research in AP Vojvodina. Anali Ekonomskog fakulteta u Subotici, 56(43), 3-13. https://doi.org/10.5937/AnEkSub2001003G

[20] Suárez-Varela, M., (2020). Dinar, A. The Role of Curtailment Versus Efficiency on Spillovers Among ProEnvironmental Behaviors: Evidence from Two Towns in Granada, Spain. Sustainability, 12(3), 769-793. https://doi.org/10.3390/su12030769

[21] Oršič, J., Rosi, B., \& Jereb, B. (2019). Measuring Sustainable Performance among Logistic Service Providers in Supply Chains. Tehnički vjesnik, 26(5), 1478-1485. https://doi.org/10.17559/TV-20180607112607

[22] Zannakis, M., Molander, S., \& Johansson, L.O. (2019). On the Relationship between Pro-Environmental Behavior, Experienced Monetary Costs, and Psychological Gains. Sustainability, 11(19), 5467-5471. https://doi.org/10.3390/su11195467

[23] Waskito, J., Imronudin, I., \& Chuzaimah, C. (2019). Observing pro-environmental behaviour based on consumer attitudes and norms. Diponegoro International Journal of Business, 2(2), 76-85. https://doi.org/10.14710/dijb.2.2.2019.76-85

[24] Muo, I. \& Azeez, A. A. (2019). Green Entrepreneurship: Literature Review and Agenda for Future Research. International Journal of Entrepreneurial Knowledge 2019, 7(2), 17-29. https://doi.org/10.2478/ijek-2019-0007

[25] Blok, V., Wesselink, R., Studynka, O., \& Kemp, R. (2015). Encouraging sustainability in the workplace: a survey on the pro-environmental behaviour of university employees. Journal of cleaner production, 106, 55-67. https://doi.org/10.1016/j.jclepro.2014.07.063

[26] Ertz, M., Karakas, F., \& Sarigöllü, E. (2016). Exploring proenvironmental behaviours of consumers: An analysis of contextual factors, attitude, and behaviours. Journal of Business Research, 69(10), 3971-3980. https://doi.org/10.1016/j.jbusres.2016.06.010

[27] Bissing-Olson, M. J., Iyer, A., Fielding, K. S., \& Zacher, H. (2013). Relationships between daily affect and proenvironmental behaviour at work: The moderating role of pro-environmental attitude. Journal of Organizational Behavior, 34(2), 156-175. https://doi.org/10.1002/job.1788

[28] Besley, T. \&Ghatak, M. (2007). Retailing public goods: The economics of corporate social responsibility. Journal of Public Economics, 91(9), 1645-1663. https://doi.org/10.1016/j.jpubeco.2007.07.006

[29] Silva, W. D. O. \& Fontana, M. E. (2020). Survey and analyses of the critical success factors in the reverse flow inventory management process for returnable packaging. Brazilian Journal of Operations \& Production Management, 17(1), 1-14. https://doi.org/10.14488/BJOPM.2020.003

[30] Awan, M. A. \& Ali, Y. (2019) Sustainable modelling in reverse logistics strategies using fuzzy MCDM. Management of Environmental Quality: An International Journal, 30(5), 1132-1151. https://doi.org/10.1108/MEQ-01-2019-0024

[31] Nuševa, D. \& Marić, R. (2017). Quick Response Logistics in Retailing as an Information Technology Based Concept. Strategic Management, 22(4), 32-38.

[32] da Cruz, N. F., Ferreira, S., Cabral, M., Simões, P., \& Marques, R. C. (2014). Packaging waste recycling in Europe: is the industry paying for it?. Waste management, 34(2), 298-308. https://doi.org/10.1016/J.WASMAN.2013.10.035

[33] Suzuki, Y., Yamaguchi, Y., Shiraishi, K., Narumi, D., \& Shimoda, Y. (2011). Analysis and modelling of the energy demand of retail stores, Proceedings of the 12th Conf. of Int. Build. Perform. Simul. Assoc., Sydney, Australia, 14-16 November, 2011; IBPSA Australia.

[34] Doh, J. P. \& Guay, T. R. (2004). Globalization and corporate social responsibility: How non-governmental organizations influence labour and environmental codes of conduct. In Management and international review; Verlag, G., Springer: Wiesbaden, Germany, 2004, 7-29.

https://doi.org/10.1007/978-3-322-90997-8_2

[35] EUR-Lex Access to European Union Law (2020). https://eur-lex.europa.eu/homepage.html.

[36] Stilo, A., Parisi, S., Delia, S., Anastasi, F., Bruno, G., \& Laganà, P. (2004). Food Security in Europe: comparison between the" Hygiene Package" and the British Retail Consortium (BRC) \& International Food Standard (IFS) protocols. Annali di igiene: medicinapreventiva $e$ di comunita, 21(4), 387-401.

[37] Li, F., Liu, X., Zhang, X., Zhao, D., Liu, H., Zhou, C., \&Wang, R. (2017). Urban ecological infrastructure: an integrated network for ecosystem services and sustainable urban systems. Journal of Cleaner Production, 163, 12-18. https://doi.org/10.1016/j.jclepro.2016.02.079

[38] Demirdöğen, G. \& Işik, Z. (2019). Environmental Scanning Approach to Assess Innovation and Technology Transfer Performance of Construction Companies. Tehnički vjesnik, 26(3), 617-624.https://doi.org/10.17559/TV-20170729163458

[39] Lee, D. (2020). Who Drives Green Innovation? A Game Theoretical Analysis of a Closed-Loop Supply Chain under Different Power Structures. Int. J. Environ. Res. Public Health, 17(7), 2274-2299. https://doi.org/10.3390/ijerph17072274

[40] Zhang, H., Zhang, Z., Tan, A., \& Steklova, E. (2020). Quantity, Quality, and Performance of Corporate Social Responsibility Information Disclosure by Listed Enterprises in China: A Regional Perspective. Int. J. Environ. Res. Public Health, 17(7), 2245-2260.

https://doi.org/10.3390/ijerph17072245

[41] Dono, J., Webb, J., \& Richardson, B. (2010). The relationship between environmental activism, pro- 
environmental behaviour and social identity. Journal of environmental psychology, 30(2), 178-186. https://doi.org/10.1016/j.jenvp.2009.11.006

[42] Gatersleben, B., Murtagh, N., \& Abrahamse, W. (2012). Values, identity and pro-environmental behaviour. Contemporary Social Science, 9(4), 374-392. https://doi.org/10.1080/21582041.2012.682086

[43] EUR-Lex Access to European Union Law. European Parliament and Council Directive 94/62/EC.

[44] Qu, L. \& Li, Y. (2019). Research on industrial policy from the perspective of demand-side open innovation-A case study of Shenzhen new energy vehicle industry. Journal of Open Innovation: Technology, Market, and Complexity, 5(2), 31-50. https://doi.org/10.3390/joitmc5020031

[45] Theeraviriya, C., Pitakaso, R., Sillapasa, K., \& Kaewman, S. (2019). Location decision making and transportation route planning considering fuel consumption. Journal of Open Innovation: Technology, Market, and Complexity, 5(2), 2745. https://doi.org/10.3390/joitmc5020027

[46] Yoo, J. \& Kim, J. (2019). The effects of entrepreneurial orientation and environmental uncertainty on Korean technology firms' R\&D investment. Journal of Open Innovation: Technology, Market, and Complexity, 5(2), 2941. https://doi.org/10.3390/joitmc5020029

[47] Kraleva, V. \& Ivanov, S. (2019). The relation activismsustainable consumption-designing the measurement instrument. Management and Sustainable Development, 75(2), 32-36.

[48] Vučenović, S. (2018). Internet of things as an innovative technology in retailing. Anali Ekonomskog fakulteta $u$ Subotici, 54(39), 249-256. https://doi.org/10.5937/AnEkSub1839249V

[49] Tešić, D. (2020). Measuring dimensions of service quality. Strategic Management, 25(1), 12-20. https://doi.org/10.5937/StraMan2001012

\section{Contact information:}

\section{Jelena KONČAR}

University of Novi Sad,

Faculty of Economics in Subotica,

Segedinski put 9-11, Subotica, Serbia

\section{Radenko MARIĆ}

University of Novi Sad,

Faculty of Economics in Subotica,

Segedinski put 9-11, Subotica, Serbia

\section{Goran VUKMIROVIĆ}

(Corresponding author)

University of Novi Sad,

Faculty of Economics in Subotica,

Segedinski put 9-11, Subotica, Serbia

E-mail: goran.vukmirovic@ef.uns.ac.rs

\section{Sonja VUČENOVIĆ}

University of Novi Sad,

Faculty of Economics in Subotica,

Segedinski put 9-11, Subotica, Serbia 